\title{
Influence of Foliar Fertilizers on Growth and Development of Petunia hybrida in Winter-Spring 2015-2016 in Thua Thien Hue
}

\author{
The Thi Dieu Nguyen ${ }^{1}$, Phuong Thi Xuan Tran ${ }^{1,3}$, Hai Thi Hong Truong ${ }^{1,2,3}$ and Khoa Dang Tran ${ }^{1,3}$ \\ 1. Hue University, 03 Le Loi Street, Hue City 530000, Vietnam \\ 2. Institute of Biotechnology, Hue University, Tinh Lo 10 Street, Hue City 530000, Vietnam \\ 3. Agronomy Faculty, University of Agriculture and Forestry, Hue University, 102 Phung Hung Street, Hue City 530000, Vietnam
}

\begin{abstract}
The experiment was conducted in winter-spring 2015-2016 in Thua Thien Hue to identify different foliar fertilizer for Petunia hybrida having good growth and development, beautiful colors and long lifetime under local conditions. The experiment included four treatments with three kinds of forliar fertilizers-Dau Trau MK 30-10-5, gibberellin 25-10-10 and abscisic acid. The control treatment $\left(\mathrm{T}_{0}\right)$ used sterilized water without foliar fertilizer. The results showed that all the foliar fertilizers influenced well on growth and development of Petunia hybrida. Dau Trau MK 30-10-5 helped Petunia hybrida have high quality and high value/cost ratio than the others.
\end{abstract}

Key words: Foliar fertilizer, Petunia hybrida, growth, Thua Thien Hue.

\section{Introduction}

Petunia hybrida or Petunia, which originated from South America [1], is a genus in the Solanaceae family and Petunioideae subfamily [2]. Petunia hybrida is variable in shape, colors and very popular in the world [3]. It is cultivated as potting and bedding flower to decorate the landscape. There were many researches conducted on this plant to find suitable fertilizer levels in order to achieve good growth as well as high quality of flowers. Hoda and Mona [4] studied the effect of bio and chemical fertilizers on growth and flowering of Petunia hybrida plants. The effect of fertilizer concentration on growth and flowering of subirrigated petunias and begonias was published by James and Van Lersel [5]. Fain et al. [6] reported the results of whole tree substrate and fertilizer rate in production of greenhouse-grown Petunia (Petunia hybrida Vilm.) and Marigold

Corresponding author: Hai Thi Hong Truong, associate professor, research field: biotechnology.
(Tagetes patula L.). Today, most Petunia hybrida are hybrid, so this flower becomes easier to grow in different soil types and temperature ranges, and does not require much maintenance. In Vietnam, there are so many kinds of flowers, and each flower has a special color, meaning and beauty. Of those, Petunia hybrida is one of flowers that was first introduced and grown in Southern provinces of Vietnam. However, the flower has high price, supply resources are not stable and lifetime of flower is decreased when changing living conditions. Thus, research on influence of fertilizers on growth, development and lifetime of Petunia hybrida in the garden at production stage is necessary. Nguyen et al. [7] studied the effect of organic and inorganic fertilizers on growth and quality of potted Begonia and Petunia hybrida.

Thua Thien Hue has typical climatic conditions of the central region, so it greatly affects on the growth and products of flowers, specially the color of flowers is always brighter than those planted in different 
provinces. Currently, in Thua Thien Hue, the demand of flowers is increasing and the floriculturists also have developed new flower varieties. Therefore, Petunia hybrida is a potential flower to develop in Thua Thien Hue. However, the development of Petunia hybrida has also limitations of technical and adaptability because of hot and humid climate conditions. The published domestic studies about effect of different fertilizers on this ornamental plant are not much. Saqib et al. [8] indicated that foliar feeding of nutrients has important role in root absorption promotion of the same nutrient or other nutrients due to improving root growth and enhancing nutrient uptake. The researches by Alexander and Schroeder [9], Fageria et al. [10] and Kannan [11] showed great potential of foliar fertilizer as a mean to reduce soil and groundwater contamination. Therefore, the purpose of this study was to evaluate the influence of foliar fertilizers under local conditions for growth, development, colors and lifetime of Petunia hybrida.

\section{Materials and Methods}

\subsection{Weather Conditions during This Experiment}

The field experiment was conducted during winter-spring season from November 2015 to April 2016 in an open field at Agronomy Faculty, University of Agriculture and Forestry, Hue University. The weather condition during experiment is presented in Table 1. In December, mean temperature was $21.8{ }^{\circ} \mathrm{C}$, with high humidity (93\%) and high number of rainy days (19 d), which were suitable for seedlings. From January to March, the temperature was always low and the humidity ranged from $91 \%$ to $93 \%$ that were favourable for growth and development of Petunia hybrida as well as flowering stage. However, the change of the temperature in April with the highest temperature during experiment $\left(27.3^{\circ} \mathrm{C}\right)$ and the highest of total sunny hours $(142 \mathrm{~h})$ led obstacle of flowering process.

\subsection{Experiment Design}

A violet Petunia hybrida variety used in this study was collected from Da Nang green tree company. The three foliar fertilizers (Dau Trau MK 30-10-5, gibberellin 25-10-10 and abscisic acid) were applied on growth and development periods of Petunia hybrida (Table 2). The control treatment $\left(\mathrm{T}_{0}\right)$ used sterilized water without foliar fertilizer. Fertilizers were used from 21 days after transplanting (DAT) to flower wilted, and periodically sprayed every 7-10 d. Components of the three foliar fertilizers are presented in Tables 3-5.

The experiment was laid out in a random complete block design (RCBD) with three replications and four treatments (Table 6). Each replication contained five plants. Petunia hybrida was planted in flowerpots with a diameter of $15 \mathrm{~cm} \times 12 \mathrm{~cm}$ containing mixture of semi-sandy soil and compost with a ratio of 1:1, which treated with Trichoderma spp..

\subsection{Agronomy Characteristic}

Quantitative and qualitative parameters were observed. Time of development periods was recorded

Table 1 Meteorological conditions recorded in winter-spring season 2015-2016.

\begin{tabular}{|c|c|c|c|c|c|c|c|c|}
\hline \multirow{2}{*}{ Month } & \multicolumn{3}{|c|}{ Temperature $\left({ }^{\circ} \mathrm{C}\right)$} & \multicolumn{2}{|c|}{ Humidity (\%) } & \multicolumn{2}{|c|}{ Rainfall } & \multirow{2}{*}{$\begin{array}{l}\text { Total sunny } \\
\text { hour }(\mathrm{h})\end{array}$} \\
\hline & $\mathrm{T}_{\text {mean }}$ & $\mathrm{T}_{\max }$ & $\mathrm{T}_{\min }$ & $\mathrm{H}_{\text {mean }}$ & $\mathrm{H}_{\min }$ & NRD (d) & $\mathrm{R}_{\text {mean }}(\mathrm{mm})$ & \\
\hline November & 25.4 & 28.7 & 23.0 & 92 & 64 & 6 & 374.3 & 43 \\
\hline December & 21.8 & 31.0 & 15.0 & 93 & 67 & 19 & 313.1 & 105 \\
\hline January & 20.9 & 23.9 & 18.8 & 93 & 66 & 19 & 124.1 & 49 \\
\hline February & 18.3 & 22.1 & 15.6 & 91 & 38 & 18 & 86.4 & 61 \\
\hline March & 22.4 & 26.8 & 19.5 & 91 & 57 & 24.8 & 24.8 & 121 \\
\hline April & 27.3 & 34.2 & 23.6 & 86 & 43 & 7 & 26.2 & 142 \\
\hline
\end{tabular}

T: temperature; H: humidity; R: rain; NRD: number of rainy days.

Source: Center for Hydrometeorology Forecast of Thua Thien Hue Province. 
Table 2 Three foliar fertilizers used.

\begin{tabular}{ll}
\hline Name of foliar fertilizers & Dose \\
\hline Dau Trau MK 30-10-5 & $10 \mathrm{~g}$ for 8-10 L water \\
Gibberellin 25-10-10 & $20 \mathrm{~g}$ for 16-20 L water \\
Abscisic acid (ABA) & $10 \mathrm{~g}$ for 8-10 L water \\
\hline
\end{tabular}

Table 3 Components of Dau Trau MK 30-10-5 foliar fertilizer.

\begin{tabular}{ll}
\hline Components & Concentration \\
\hline Total $\mathrm{N}$ & $30 \%$ \\
Effective $\mathrm{P}_{2} \mathrm{O}_{5}$ & $10 \%$ \\
Effective $\mathrm{K}_{2} \mathrm{O}$ & $5 \%$ \\
$\mathrm{CaO}$ & $0.05 \%$ \\
$\mathrm{MgO}$ & $0.05 \%$ \\
$\mathrm{Zn}$ & $500 \mathrm{ppm}$ \\
$\mathrm{B}$ & $100 \mathrm{ppm}$ \\
$\mathrm{Cu}$ & $500 \mathrm{ppm}$ \\
$\mathrm{Humidity}$ & $2 \%$ \\
\hline
\end{tabular}

Table 4 Components of gibberellin 25-10-10 foliar fertilizer.

\begin{tabular}{ll}
\hline Components & Percentage (\%) \\
\hline $\mathrm{N}$ & 25 \\
$\mathrm{P}_{2} \mathrm{O}_{5}$ & 10 \\
$\mathrm{~K}_{2} \mathrm{O}$ & 10 \\
\hline
\end{tabular}

Table 5 Components of abscisic acid (ABA).

\begin{tabular}{ll}
\hline Components & Percentage (\%) \\
\hline $\mathrm{N}$ & 5 \\
$\mathrm{P}_{2} \mathrm{O}_{5}$ & 30 \\
$\mathrm{~K}_{2} \mathrm{O}_{5}$ & 30 \\
ANA & 0.4 \\
BNA & 0.1 \\
\hline ANA: alpha
\end{tabular}

ANA: alpha naphthalene acetic acid; BNA: beta naphtoxy acetic acid.

Table 6 Experimental treatments.

\begin{tabular}{ll}
\hline Treatments & Formulation \\
\hline $\mathrm{T}_{0}$ (control) & Water \\
$\mathrm{T}_{1}$ & Dau Trau MK 30-10-5 \\
$\mathrm{T}_{2}$ & Gibberellin 25-10-10 \\
$\mathrm{T}_{3}$ & ABA \\
\hline
\end{tabular}

from transplanting to appearing the 1st flower-bud, the 1st flower flowering and the 1st flower wilted. Ability of growth, including plant height, number of leaves and plant diameter, was measured from 7 DAT to 98 DAT. Flowering progress started from 10 weeks to 17 weeks after transplanting (WAT). Ability of development was counted including number of flower buds, number of flowers and percentage of effective flowers (\%). Flower quality was formed by flower diameter, lifetime of flowers and flower color. Of those, the flower diameter was the widest of flower, the lifetime of flowers was recorded from flower flowering to flower wilted and the flower color was observed by sensory method.

The economic efficiency was calculated as the following Eqs. (1) and (2):

$$
\text { Income }=\text { total revenue }- \text { total expenditure }
$$

where, total revenue: money that florist obtained from a pot; total expenditure $=$ expenses of unused fertilizer (expenses increased due to fertilizer application).

$$
\begin{aligned}
& \text { Value-cost ratio }(\mathrm{VCR})= \\
& \text { value products increased by fertilizing }
\end{aligned}
$$

expenses increased due to fertilizer application

\subsection{Analysis Method}

Data were calculated by Excel 2007 and analyzed by statistical software Statistix 9.0.

\section{Results and Discussion}

\subsection{Time of Development Periods}

Time from transplanting to appearing the first bud ranged from $66 \mathrm{~d}$ to $78 \mathrm{~d}$. Treatment $\mathrm{T}_{1}$ showed the earliest time for budding with $66 \mathrm{~d}$, followed by treatment $T_{2}$ with $72 \mathrm{~d}$ and $T_{3}$ with $73 \mathrm{~d}$. The control treatment had the latest time for budding with $78 \mathrm{~d}$ (Table 7).

Time from transplanting to the first flower of all treatments with application of foliar fertilizers was shorter than those in the control $\mathrm{T}_{0}$ (84 DAT). The first flower appeared the earliest in the treatment $T_{1}$ with 70 DAT, followed by treatments $T_{2}$ and $T_{3}$ with 77 DAT. Time from transplanting to the first flower wilted in the treatment $T_{0}$ was the longest with $89 \mathrm{~d}$. However, the interval time between the first flower flowering and the first flower wilted in treatment $T_{1}$ was shorter than the remained treatments. 
Table 7 Influence of foliar fertilizers on development periods of Petunia hybrida.

\begin{tabular}{llll}
\hline \multirow{2}{*}{ Treatments } & \multicolumn{3}{l}{ Time (DAT) from transplanting to } \\
\cline { 2 - 4 } & Appearing the 1st flower-bud & The 1st flower flowering & The 1st flower wilted \\
\hline $\mathrm{T}_{0}$ & 78 & 84 & 89 \\
$\mathrm{~T}_{1}$ & 66 & 70 & 78 \\
$\mathrm{~T}_{2}$ & 72 & 77 & 84 \\
$\mathrm{~T}_{3}$ & 73 & 77 & 83 \\
\hline
\end{tabular}

Table 8 Influence of foliar fertilizers on plant height of Petunia hybrida.

\begin{tabular}{|c|c|c|c|c|c|}
\hline \multirow{2}{*}{ DAT } & \multicolumn{4}{|c|}{ Plant height $(\mathrm{cm})$} & \multirow{2}{*}{$-\mathrm{LSD}_{0.05}$} \\
\hline & $\mathrm{T}_{0}$ & $\mathrm{~T}_{1}$ & $\mathrm{~T}_{2}$ & $\mathrm{~T}_{3}$ & \\
\hline 7 & $9.37^{\mathrm{a}}$ & $11.23^{\mathrm{a}}$ & $9.40^{\mathrm{a}}$ & $9.23^{\mathrm{a}}$ & 2.45 \\
\hline 14 & $11.23^{\mathrm{a}}$ & $13.47^{\mathrm{a}}$ & $13.70^{\mathrm{a}}$ & $12.93^{\mathrm{a}}$ & 2.71 \\
\hline 21 & $14.07^{c}$ & $18.20^{\mathrm{ab}}$ & $20.93^{\mathrm{a}}$ & $18.03^{\mathrm{b}}$ & 2.87 \\
\hline 28 & $15.20^{\mathrm{b}}$ & $20.87^{\mathrm{a}}$ & $23.67^{\mathrm{a}}$ & $21.27^{\mathrm{a}}$ & 5.03 \\
\hline 35 & $17.13^{\mathrm{b}}$ & $22.07^{\mathrm{ab}}$ & $25.00^{\mathrm{a}}$ & $22.87^{\mathrm{a}}$ & 5.09 \\
\hline 42 & $19.70^{\mathrm{b}}$ & $23.23^{\mathrm{ab}}$ & $26.27^{\mathrm{a}}$ & $24.13^{\mathrm{ab}}$ & 5.37 \\
\hline 49 & $20.67^{\mathrm{b}}$ & $24.23^{\mathrm{ab}}$ & $27.80^{\mathrm{a}}$ & $24.87^{\mathrm{ab}}$ & 5.24 \\
\hline 56 & $23.53^{\mathrm{a}}$ & $27.77^{\mathrm{a}}$ & $29.17^{\mathrm{a}}$ & $26.80^{\mathrm{a}}$ & 6.34 \\
\hline 63 & $25.90^{\mathrm{b}}$ & $31.60^{\mathrm{a}}$ & $30.80^{\mathrm{ab}}$ & $28.57^{\mathrm{ab}}$ & 5.08 \\
\hline 70 & $27.53^{\mathrm{b}}$ & $34.07^{\mathrm{a}}$ & $32.17^{\mathrm{ab}}$ & $31.76^{\mathrm{ab}}$ & 5.15 \\
\hline 77 & $28.73^{\mathrm{b}}$ & $35.43^{\mathrm{a}}$ & $33.67^{\mathrm{a}}$ & $32.87^{\mathrm{ab}}$ & 4.88 \\
\hline 84 & $31.43^{\mathrm{a}}$ & $35.83^{\mathrm{a}}$ & $35.03^{\mathrm{a}}$ & $33.47^{\mathrm{a}}$ & 4.79 \\
\hline 91 & $31.90^{\mathrm{a}}$ & $36.03^{\mathrm{a}}$ & $35.23^{\mathrm{a}}$ & $33.60^{\mathrm{a}}$ & 4.67 \\
\hline 98 & $32.03^{\mathrm{a}}$ & $36.20^{\mathrm{a}}$ & $35.33^{\mathrm{a}}$ & $33.73^{\mathrm{a}}$ & 4.70 \\
\hline
\end{tabular}

${ }^{\mathrm{a}-\mathrm{c}}$ Different letters in each column indicate different means at $\alpha=0.05$.

\subsection{Plant Height}

Plant height is controlled by genetics, but also influenced by environmental factors, such as temperature, sunlight, soil nutrition and other cultivation techniques. Plant height is one of the morphological indicators to assess the growth, development and yield. On the other hand, it also reflects ability of organic accumulation of the plant. Progress of plant height influenced by foliar fertilizers is presented in Table 8.

At 7 DAT and 14 DAT, plant height in all treatments had no significant difference, because foliar fertilizers had not been used in this time. In the next periods, plant height of Petunia hybrida increased quickly, due to that application foliar fertilizers affected on plant height. At 21 DAT, plants in the treatment $\mathrm{T}_{2}$ presented the highest height with $20.93 \mathrm{~cm}$, followed by treatment $T_{1}(18.20 \mathrm{~cm})$ and $T_{3}(18.03 \mathrm{~cm})$. The shortest plants were observed in the control treatment $\left(\mathrm{T}_{0}\right)$ with $14.07 \mathrm{~cm}$. The plant height in the treatment $\mathrm{T}_{2}$ maintained the tallest until 56 DAT.

At 63 DAT and 70 DAT, plant height increased rapidly in the treatment $\mathrm{T}_{1}$ to $31.60 \mathrm{~cm}$ and $34.07 \mathrm{~cm}$, respectively. From 84 DAT to 98 DAT, plant height in all treatment growing slowly, because trees had achieved a certain height and focused on nutrient to form flowers. Plant height ranged from $32.03 \mathrm{~cm}$ to $36.20 \mathrm{~cm}$.

In summary, the growth rate of the plant height for Petunia hybrida in all treatments which used the foliar fertilizers was higher than those in the contol treatment $\mathrm{T}_{0}$.

\subsection{Number of Leaves}

Number of leaves of Petunia hybrida is presented in Table 9. From 7 DAT to 21 DAT, the number of 
leaves in all treatments was not significantly different, because the root was still weak to absorb more nutrients and this period foliar fertilizer had not been used.

From 21 DAT to 70 DAT, the number of leaves of Petunia hybrida was influenced by the use of foliar fertilizers. The treatment $T_{1}$ had the highest number of leaves and the lowest was observed in the control check $\left(\mathrm{T}_{0}\right)$.

From 70 DAT to 84 DAT, the number of leaves was significantly different among the treatments and increased rapidly. AT 84 DAT, the treatment $T_{1}$ still had the highest leaf number with 57.40 leaves, followed by treatment $T_{2}$ with 53.13 leaves, $T_{3}$ with 50.20 leaves and the control check $\left(\mathrm{T}_{0}\right)$ with 47.27 leaves.

From 84 DAT to 98 DAT, the number of leaves increased slowly, because the plant gained the maximum leaf number at this stage.

Thus, the number of leaves of Petunia hybrida showed significant difference at different stages, especially, the treatment $T_{1}$ with use of Dau Trau MK 30-10-5.

\subsection{Plant Diameter}

Plant diameter is a good indicator of the plant's morphological characteristics for studies of plant health, as it is a measurement of growth through leaf production. The large plant diameter will increase assimilation and photosynthesis.

Table 10 showed influence of foliar fertilizers on plant diameter of Petunia hybrida. From 7 DAT to 14 DAT, the treatment $\mathrm{T}_{0}$ had the smallest plant diameter and the largest was obtained in the treatment $\mathrm{T}_{1}$. At 7 DAT, it ranged from $8.80 \mathrm{~cm}\left(\mathrm{~T}_{0}\right)$ to $9.63 \mathrm{~cm}\left(\mathrm{~T}_{1}\right)$.

From 28 DAT to 35 DAT, the plant diameter of the treatment $\mathrm{T}_{1}$ increased rapidly, ranging from $21.93 \mathrm{~cm}$ to $29.20 \mathrm{~cm}$, respectively. After $70 \mathrm{DAT}$, the plant diameter ranged from $40.73 \mathrm{~cm}\left(\mathrm{~T}_{0}\right)$ to $48.27 \mathrm{~cm}\left(\mathrm{~T}_{1}\right)$.

From 70 DAT to 98 DAT, the plants absorbed more nutrients for flower-bud formation and flowering, so the plant diameter increased steadily and was significantly difference among treatments.

In general, Petunia hybrida was suitable for foliar fertilizer Dau Trau MK 30-10-5 than other foliar fertilizers.

\subsection{Flowering Progress}

Table 11 recorded the number of flowers of Petunia hybrida. There was no significant difference on number of flowers among treatments at 10 WAT. From 11 WAT to 14 WAT, the number of flowers showed significant difference between treatments.

Table 9 Influence of foliar fertilizers on number of leaves of Petunia hybrida.

\begin{tabular}{llllll}
\hline \multirow{2}{*}{ Days after planting } & \multicolumn{5}{c}{ Number of leaves } \\
\cline { 2 - 5 } & $\mathrm{T}_{0}$ & $\mathrm{~T}_{1}$ & $\mathrm{~T}_{2}$ & $\mathrm{~T}_{3}$ & 0.81 \\
\hline 7 & $4.20^{\mathrm{b}}$ & $5.40^{\mathrm{a}}$ & $5.87^{\mathrm{a}}$ & $5.20^{\mathrm{a}}$ & 0.25 \\
14 & $8.47^{\mathrm{a}}$ & $8.53^{\mathrm{a}}$ & $8.60^{\mathrm{a}}$ & $8.50^{\mathrm{a}}$ & 0.66 \\
21 & $12.43^{\mathrm{a}}$ & $12.50^{\mathrm{a}}$ & $12.50^{\mathrm{a}}$ & $12.40^{\mathrm{a}}$ & 0.73 \\
28 & $15.80^{\mathrm{c}}$ & $19.27^{\mathrm{a}}$ & $17.20^{\mathrm{b}}$ & $16.07^{\mathrm{c}}$ & 0.81 \\
35 & $20.93^{\mathrm{c}}$ & $25.27^{\mathrm{a}}$ & $21.93^{\mathrm{b}}$ & $21.13^{\mathrm{bc}}$ & 1.12 \\
42 & $25.27^{\mathrm{b}}$ & $30.00^{\mathrm{a}}$ & $26.27^{\mathrm{b}}$ & $25.40^{\mathrm{b}}$ & 1.56 \\
49 & $29.07^{\mathrm{b}}$ & $34.93^{\mathrm{a}}$ & $30.53^{\mathrm{b}}$ & $29.33^{\mathrm{b}}$ & 0.86 \\
56 & $32.33^{\mathrm{d}}$ & $39.60^{\mathrm{a}}$ & $35.67^{\mathrm{b}}$ & $33.33^{\mathrm{c}}$ & 1.80 \\
70 & $36.60^{\mathrm{c}}$ & $43.53^{\mathrm{a}}$ & $40.93^{\mathrm{b}}$ & $38.13^{\mathrm{c}}$ & 2.34 \\
84 & $41.07^{\mathrm{c}}$ & $48.00^{\mathrm{a}}$ & $45.47^{\mathrm{b}}$ & $42.07^{\mathrm{c}}$ & 2.16 \\
91 & $44.27^{\mathrm{c}}$ & $52.20^{\mathrm{a}}$ & $49.73^{\mathrm{b}}$ & $46.60^{\mathrm{c}}$ & 2.32 \\
\hline 8 & $47.27^{\mathrm{d}}$ & $57.40^{\mathrm{a}}$ & $53.13^{\mathrm{b}}$ & $50.20^{\mathrm{c}}$ & 2.75 \\
\hline
\end{tabular}

${ }^{\mathrm{a}-\mathrm{d}}$ Different letters in each column indicate different means at $\alpha=0.05$. 
Table 10 Influence of foliar fertilizers on plant diameter of Petunia hybrida.

\begin{tabular}{|c|c|c|c|c|c|}
\hline \multirow{2}{*}{ Days after planting } & \multicolumn{4}{|c|}{ Plant diameter $(\mathrm{cm})$} & \multirow{2}{*}{$-\mathrm{LSD}_{0.05}$} \\
\hline & $\mathrm{T}_{0}$ & $\mathrm{~T}_{1}$ & $\mathrm{~T}_{2}$ & $\mathrm{~T}_{3}$ & \\
\hline 7 & $8.80^{\mathrm{b}}$ & $9.63^{\mathrm{a}}$ & $9.20^{\mathrm{ab}}$ & $8.93^{\mathrm{b}}$ & 0.68 \\
\hline 14 & $11.83^{\mathrm{a}}$ & $13.00^{\mathrm{a}}$ & $12.67^{\mathrm{a}}$ & $12.37^{\mathrm{a}}$ & 1.31 \\
\hline 21 & $15.77^{\mathrm{b}}$ & $17.30^{\mathrm{a}}$ & $16.70^{\mathrm{ab}}$ & $15.93^{\mathrm{b}}$ & 0.94 \\
\hline 28 & $20.17^{\mathrm{a}}$ & $21.93^{\mathrm{a}}$ & $20.80^{\mathrm{a}}$ & $20.20^{\mathrm{a}}$ & 2.02 \\
\hline 35 & $23.53^{c}$ & $29.20^{\mathrm{a}}$ & $25.93^{\mathrm{b}}$ & $24.53^{\mathrm{bc}}$ & 1.88 \\
\hline 42 & $26.83^{\mathrm{C}}$ & $33.23^{\mathrm{b}}$ & $30.23^{\mathrm{b}}$ & $27.60^{\mathrm{c}}$ & 2.34 \\
\hline 49 & $30.60^{c}$ & $39.20^{\mathrm{a}}$ & $34.93^{\mathrm{b}}$ & $31.53^{c}$ & 1.48 \\
\hline 56 & $33.27^{\mathrm{b}}$ & $41.60^{\mathrm{a}}$ & $38.07^{\mathrm{ab}}$ & $35.73^{\mathrm{ab}}$ & 3.73 \\
\hline 63 & $36.77^{\mathrm{b}}$ & $44.80^{\mathrm{a}}$ & $40.40^{\mathrm{b}}$ & $39.40^{\mathrm{b}}$ & 1.51 \\
\hline 70 & $40.73^{\mathrm{b}}$ & $48.27^{\mathrm{a}}$ & $44.87^{\mathrm{ab}}$ & $40.73^{b}$ & 5.75 \\
\hline 77 & $43.80^{\mathrm{b}}$ & $51.43^{\mathrm{a}}$ & $48.87^{\mathrm{ab}}$ & $46.13^{\mathrm{ab}}$ & 6.08 \\
\hline 84 & $46.43^{\mathrm{b}}$ & $53.77^{\mathrm{a}}$ & $50.53^{\mathrm{ab}}$ & $47.80^{\mathrm{ab}}$ & 6.21 \\
\hline 91 & $49.07^{\mathrm{b}}$ & $55.43^{\mathrm{ab}}$ & $52.13^{\mathrm{ab}}$ & $49.43^{\mathrm{b}}$ & 5.91 \\
\hline 98 & $50.37^{\mathrm{b}}$ & $56.70^{\mathrm{a}}$ & $53.73^{\mathrm{ab}}$ & $51.40^{\mathrm{ab}}$ & 6.11 \\
\hline
\end{tabular}

${ }^{\mathrm{a}-\mathrm{c}}$ Different letters in each column indicate different means at $\alpha=0.05$.

Table 11 Flowering progress of Petunia hybrida.

\begin{tabular}{lllllllll}
\hline \multirow{2}{*}{ Treatments } & \multicolumn{7}{c}{ Number of flowers/plant at WAT } \\
\cline { 2 - 9 } & 10 & 11 & 12 & 13 & 14 & 15 & 16 & 17 \\
\hline $\mathrm{T}_{0}$ & $0.00^{\mathrm{a}}$ & $0.00^{\mathrm{b}}$ & $4.67^{\mathrm{b}}$ & $9.67^{\mathrm{c}}$ & $9.33^{\mathrm{c}}$ & $10.33^{\mathrm{c}}$ & $9.33^{\mathrm{c}}$ & $7.00^{\mathrm{d}}$ \\
$\mathrm{T}_{1}$ & $0.67^{\mathrm{a}}$ & $6.00^{\mathrm{a}}$ & $12.00^{\mathrm{a}}$ & $21.67^{\mathrm{a}}$ & $28.67^{\mathrm{a}}$ & $26.33^{\mathrm{a}}$ & $26.33^{\mathrm{a}}$ & $20.67^{\mathrm{a}}$ \\
$\mathrm{T}_{2}$ & $0.00^{\mathrm{a}}$ & $1.33^{\mathrm{ab}}$ & $8.67^{\mathrm{ab}}$ & $18.00^{\mathrm{ab}}$ & $21.33^{\mathrm{b}}$ & $19.67^{\mathrm{b}}$ & $21.00^{\mathrm{ab}}$ & $18.67^{\mathrm{c}}$ \\
$\mathrm{T}_{3}$ & $0.00^{\mathrm{a}}$ & $1.00^{\mathrm{ab}}$ & $7.33^{\mathrm{ab}}$ & $17.33^{\mathrm{b}}$ & $17.67^{\mathrm{b}}$ & $16.33^{\mathrm{b}}$ & $15.67^{\mathrm{b}}$ & $14.33^{\mathrm{c}}$ \\
\hline $\mathrm{LSD}_{0.05}$ & 1.15 & 5.06 & 6.62 & 4.23 & 5.72 & 4.35 & 6.31 & 1.60 \\
\hline
\end{tabular}

${ }^{\mathrm{a}-\mathrm{d}}$ Different letters in each column indicate different means at $\alpha=0.05$.

At 14 WAT, number of flowers ranged from $9.33\left(\mathrm{~T}_{0}\right)$ to 28.67 flowers $\left(T_{1}\right)$. While treatment $T_{1}$ gained the highest number of flowers (28.67 flowers), followed by treatment $T_{2}$ (21.33 flowers) and treatment $T_{3}$ (17.67 flowers), treatment $T_{0}$ obtained the lowest number of flowers (9.33 flowers).

From 15 WAT to 17 WAT, the number of flowers in all treatments decreased steadily. The treatment $\mathrm{T}_{1}$ still gained the highest number of flowers with 20.67 flowers. Whereas, the control check $\left(T_{0}\right)$ had the lowest number of flowers with 7.00 flowers.

\subsection{Percentage of Effective Flowers}

The influence of foliar fertilizers on the number of flower-bud, number of flowers and percentage of effective flowers is presented in Table 12. The number of flower-bud is an important characteristic to evaluate flower quality. For Petunia hybrida, foliar fertilizer Dau Trau MK 30-10-5 $\left(\mathrm{T}_{1}\right)$ showed the best influence on the number of flower-bud (150.67 flower-buds), number of flowers (142.33 flowers) and the percentage of effective flowers (94.46\%). Thus, treatment $T_{1}$ gained the highest percentage of effective flowers among the treatments, followed by treatment $\mathrm{T}_{2}(91.32 \%)$ and $\mathrm{T}_{3}(90.88 \%)$. The number of flower buds in this study was higher than that reported by Pham et al. [12] in Hanoi, Vietnam, where Atonik 1.8DD, Komix BEC 201 and Dau Trau 702 foliar fertilizer were applied to Torenia fournieri Linden and the number of flower buds ranged from 37.9 to 51.6.

\subsection{Flower Quality}

Flower quality is an important factor to increase 
Table 12 Percentage of effective flowers.

\begin{tabular}{llll}
\hline Treatments & Number of flower-bud & Number of flowers & Percentage of effective flowers (\%) \\
\hline $\mathrm{T}_{0}$ & $58.67^{\mathrm{d}}$ & $50.33^{\mathrm{c}}$ & 85.78 \\
$\mathrm{~T}_{1}$ & $150.67^{\mathrm{a}}$ & $142.33^{\mathrm{a}}$ & 94.46 \\
$\mathrm{~T}_{2}$ & $119.00^{\mathrm{b}}$ & $108.67^{\mathrm{b}}$ & 91.32 \\
$\mathrm{~T}_{3}$ & $98.67^{\mathrm{c}}$ & $89.67^{\mathrm{c}}$ & 90.88 \\
\hline $\mathrm{LSD}_{0.05}$ & 10.32 & 10.36 & - \\
\hline
\end{tabular}

a-d Different letters in each column indicate different means at $\alpha=0.05$.

Table 13 Influence of foliar fertilizers on flower quality of Petunia hybrida.

\begin{tabular}{llll}
\hline Treatments & Flower diameter $(\mathrm{cm})$ & Lifetime of flowers (day) & Flower color \\
\hline $\mathrm{T}_{0}$ & $4.43^{\mathrm{d}}$ & $3.78^{\mathrm{d}}$ & Violet \\
$\mathrm{T}_{1}$ & $5.39^{\mathrm{a}}$ & $7.03^{\mathrm{a}}$ & Violet \\
$\mathrm{T}_{2}$ & $5.15^{\mathrm{b}}$ & $5.43^{\mathrm{b}}$ & Violet \\
$\mathrm{T}_{3}$ & $4.92^{\mathrm{c}}$ & $4.67^{\mathrm{c}}$ & Violet \\
\hline $\mathrm{LSD}_{0.05}$ & 0.16 & 0.27 & - \\
\hline
\end{tabular}

${ }^{\mathrm{a}-\mathrm{d}}$ Different letters in each column indicate different means at $\alpha=0.05$.

Table 14 Economic efficiency of foliar fertilizers for Petunia hybrida.

\begin{tabular}{lllllll}
\hline \multirow{2}{*}{ Treatments } & \multicolumn{5}{c}{ Economic efficiency (VND) } \\
\cline { 2 - 6 } & Total revenue & Total expenditure & Income & $\begin{array}{l}\text { Value products increased } \\
\text { by fertilizer }\end{array}$ & $\begin{array}{l}\text { Production cost } \\
\text { increased by fertilizer }\end{array}$ & Value-cost ratio \\
\hline $\mathrm{T}_{0}$ & 22,000 & 16,750 & 5,250 & - & - & - \\
$\mathrm{T}_{1}$ & 35,000 & 17,550 & 17,450 & 12,200 & 800 & 15.25 \\
$\mathrm{~T}_{2}$ & 30,000 & 17,480 & 12,520 & 7,270 & 730 & 9.96 \\
$\mathrm{~T}_{3}$ & 30,000 & 17,550 & 12,450 & 7,200 & 800 & 9.00 \\
\hline
\end{tabular}

flower value. It is expressed by flower diameter, lifetime of flowers and flower color. The flower quality depends on many elements, such as weather conditions, techniques and variety.

Flower diameter of Petunia hybrida showed significant difference among treatments and ranged from $4.43 \mathrm{~cm}$ (T0) to $5.39 \mathrm{~cm}$ (T1). The flower diameter in the treatment $\mathrm{T} 1, \mathrm{~T} 2$ and $\mathrm{T} 3$ was larger than those in the control check (T0) with 5.39, 5.15, 4.92 and $4.43 \mathrm{~cm}$, respectively. These results were similar to the results obtained by Sardoei et al. [13] who conducted zinc sulphate and salicylic acid on Petunia hybrida plant with flower diameter in range of 4.54-5.13 cm.

The lifetime of flowers is also an important factor to increase the flower quality. It is based on many different elements, such as fertilizers and weather conditions. Table 13 shows that using foliar fertilizers helped flowers to have longer lifetime.

It is clear from Table 13 that Petunia hybrida in all treatments had same flower color (violet), because this research used same Petunia hybrida variety. Thus, foliar fertilizers used in this experiment did not affect flower color and treatment $\mathrm{T}_{1}$ gained the best flower quality among the treatments.

\subsection{Economic Efficiency}

Table 14 shows the economic efficiency of treatments. It was found that economic efficiency in treatments with foliar fertilizers was higher than those in the control $\left(\mathrm{T}_{0}\right)$. The difference in investment cost among treatments was not very high only from 16,750 VND/plot $\left(T_{0}\right)$ to 17,550 VND/plot $\left(T_{1}, T_{3}\right)$.

The treatment $T_{1}, T_{2}$ and $T_{3}$ had higher investment cost than $T_{0}$. However, total revenue and value products increased by using fertilizer. The treatment 
$\mathrm{T}_{1}$ gained the highest total revenue with 35,000 VND/plot.

Value-cost ratio can be accepted by fertilizer investment, which is a factor reflecting the economic efficiency. The treatment $T_{1}$ had the highest index with 15.25 , followed by treatment $T_{2}$ (9.96), and the control check $\left(\mathrm{T}_{0}\right)$ had the lowest. As a result, investment of foliar fertilizers for Petunia hybrida gave high value-cost ratio.

\section{Conclusions}

Foliar fertilizers used in the experiment well affected the growth and development of Petunia hybrida, compared with no use of fertilizer formula, especially Dau Trau MK 30-10-5 and gibberellin. The application of foliar fertilizers also achieved high economic efficiency for value of Petunia hybrida. In particular, using Dau Trau MK 30-10-5 obtained high value-cost ratio with 15.25. Thus, from transplanting to the first flower wilt of Petunia hybrida, Dau Trau MK 30-10-5 and gibberellin should be sprayed every $7 \mathrm{~d}$.

\section{References}

[1] Maberly, D. J. 1990. The Plant Book: A Portable Dictionary of the Higher Plants. Cambridge, U.K.: Cambridge University Press.

[2] Natural Resources Conservation Service. 2009. Classification for Kingdom Plantae Down to Family Solanaceae. United States Department of Agriculture, Natural Resources Conservation Service.

[3] Stehmann, J. R., Lorenz-Lemke, A. P., Freitas, L. B., and Semir, J. 2009. "The Genus Petunia." In Petunia: Evolutionary, Developmental and Physiological Genetics, edited by Gerats, T., and Strommer, J. New York: Springer, 1-28.
[4] Hoda, E. E., and Mona, S. 2014. "Effect of Bio and Chemical Fertilizers on Growth and Flowering of Petunia hybrida Plants." American Joural of Plant Physiology 9 (2): 68-77.

[5] James, E. C., and Van Lersel, M. W. 2001. "Fertilizer Concentration Affects Growth and Flowering of Subirrigated Petunias and Begonias.” HortScience 36 (1): 40-4.

[6] Fain, G. B., Gilliam, C. H., Sibley, J. L., and Boyer, C. R. 2008. "Whole Tree Substrate and Fertilizer Rate in Production of Greenhouse-Grown Petunia (Petunia hybrida Vilm.) and Marigold (Tagetes patula L.)." HortScience 43 (3): 700-5.

[7] Nguyen, N. T, Vu, T. N., Dong, G. H., Tang, L. H., and Chang, Y. N. 2015. "Effect of Organic and Inorganic Fertilizers on Growth and Flower Quality of Potted Begonia and Petunia hybrida." Journal of Science and Development 13 (8): 1343-51.

[8] Saqib, M., Zörb, C., and Schubert, S. 2006. "Salt-Resistant and Salt-Sensitive Wheat Genotypes Show Similar Biochemical Reaction at Protein Level in the First Phase of Salt Stress.” Journal of Plant Nutrition and Soil Science 169 (4): 542-8.

[9] Alexander, A., and Schroeder, M. 1987. "Fertilizer use Efficiency: Modern Trends in Foliar Fertilization.” Journal of Plant Nutrition 10: 1391-9.

[10] Fageria, N. K., Barbosa-Filho, M. P., Moreira, A., and Guimarães, C. M. 2009. "Foliar Fertilization of Crop Plants.” Journal of Plant Nutrition 32 (6): 1044-64.

[11] Kannan, S. 2010. "Foliar Fertilization for Sustainable Crop Production.” In Genetic Engineering, Biofertilisation, Soil Quality and Organic Farming. Heidelberg, Germany: Springer, 371-402.

[12] Pham, P. T. M., Trinh, D. T. M., Vu, L. V., Nguyen, T. D., and Do, L. T. T. 2010. "The Effect of Some Techniques on the Growth and Development of Potted Torenia (Torenia fournieri Linden)." Journal of Science and Development 8 (4): 615-21. (in Vietnamese)

[13] Sardoei, A. S., Shahdadneghad, M., Yazdi, M. R., and Gholamshahi, S. 2014. "Growth Response of Petunia hybrida to Zinc Sulphate and Salicylic Acid.” Int. J. Advanced Biological and Biomedical Res. 2 (3): 622-7. 